\title{
New acquisitions of our library
}

Campbell, J., ed. (1980(1964)). Man and transformation. Papers from the Eranos Yearbooks. Bollingen Series XXX, Vol. 5. - Princeton, University Press, xviii +415 pp.

Chatelier, H. le (1925). Science et Industrie. - Paris, Ernest Flammarion, Bibl. de Philosophie Scientifique, $283 \mathrm{pp}$.

Comte, A. (1930). La philosophie positive. II. Physique - chimie - biologie. Résumé par Emile Rigolage. - Paris, Ernest Flammarion, viii + 296 pp.

Egerton, F.N. (1973). Changing concepts of the balance of nature. - The quarterly review of biology, vol. 48 , p. 322-350.

Glas, E. (1979). Chemistry and physiology in their historical and philosophical relations. - Delft, University Press, xiii + 199 pp.

Grant, V. (1981). The genetic goal of speciation. - Biol. Zbl. 100, p. 473-482.

Haeckel, E. (1910, 6e verb. druk). Anthropogenie oder Entwicklungsgeschichte des Menschen. Keimes- und Stammesgeschichte. - Leipzig, Verlag von Wilhelm Engelmann, xxviii + 992 pp.

Jeuken, M. (1981). Voordrachtenserie "Mens en Evolutie". - Radio Nederland Wereldomroep, $20 \mathrm{pp}$.

Randolph, S.E. and Rogers, D.J. (1981). Physiological correlates of the availability of Glossina morsitans centralis Machado to different sampling methods. - Ecological Entomology, 6, p. 63-77.

Rothschuh, K.E. (1968). Physiologie. Der Wandel ihrer Konzepte, Probleme und Methoden vom 16. bis 20. Jahrhundert. - Freiburg, München, Verlag Karl Alber, 407 pp.

TNO Jaarverslag (1980). Werkoverzicht, Gezondheidsorganisatie, Centrale Organisatie Deel I en II, Voedingsorganisatie en Rijksverdedigingsorganisatie. 